\title{
A new one-pot synthesis of 1,2,4-oxadiazoles from aryl nitriles, hydroxylamine and crotonoyl chloride
}

\author{
MASOUMEH ZAKERI ${ }^{\mathrm{a}, *}$, MAJID M HERAVI $^{\mathrm{b}, *}$ and EBRAHIM ABOUZARI-LOTF ${ }^{\mathrm{c}}$ \\ ${ }^{a}$ Young Researchers and Elites Club, North Tehran Branch, Islamic Azad University, Tehran 15742, Iran \\ ${ }^{b}$ Department of Chemistry, School of Sciences, Alzahra University, 1993891176, Vanak, Tehran, Iran \\ ${ }^{\mathrm{c}}$ Institute of Hydrogen Economy, Energy Research Alliance, International Campus, Universiti Teknologi \\ Malaysia, Kuala Lumpur 54100, Malaysia \\ e-mail: ms.zakeri@gmail.com; mmh1331@yahoo.com
}

MS received 27 September 2012; revised 9 December 2012; accepted 21 January 2013

\begin{abstract}
The reaction of aryl nitriles with hydroxylamine using acetic acid as a catalyst followed by subsequent addition of crotonoyl chloride to the intermediate amidoxime represents a straightforward one-pot access to new 1,2,4-oxadiazole synthesis under mild conditions. The course of the reaction was found to be high yielding and all new compounds were well characterized by nuclear magnetic resonance (NMR), mass spectrometry (MS) and elemental analysis.
\end{abstract}

Keywords. 1,2,4-Oxadiazole; crotonoyl chloride; amidoxime; hydroxylamine.

\section{Introduction}

1,2,4-Oxadiazoles are well-known compounds with promising physiological activities. ${ }^{1-3}$ Oxadiazoles have also shown activity as benzodiazepine receptor partial agonists, ${ }^{4}$ dopamine receptor $\left(\mathrm{D}_{4}\right)$ ligands, growth hormone secretogogues, ${ }^{5}$ antispasmodics, antiinflammatory agents and antithrombotic agents. ${ }^{6}$ Thus, they have received considerable attention during the last two decades in the drug discovery programmes ${ }^{7}$ and development of clean, safe, effective, economical and high-yielding synthesis routes is still desirable and is in demand.

The general synthesis of oxadiazoles involves the reaction of arylnitriles with hydroxylamine and coupling of a prepared amidoxime with an activated carboxyl group, yielding an O-acyl amidoxime followed by its dehydrative cyclization. ${ }^{8-10}$ Cyclization of the O-acyl amidoxime is generally the most difficult and time-consuming step and often requires multi-step procedures, ${ }^{11}$ silica gel column, ${ }^{12}$ exhaustive reflux conditions in dimethylformamide (DMF) or pyridine ${ }^{13}$ and the use of a strong base such as alumina-supported ammonium fluoride, ${ }^{14} \mathrm{MgO}^{15}$ and $\mathrm{KF}^{16}$ as catalysts and solid supports. It has been reported that 1,2,4-oxadiazoles can be prepared from an amidoxime and carboxylic acids derivatives through a one-pot reaction. ${ }^{17}$ However, ami-

*For correspondence doxime needs to be prepared from commercially available arylnitriles in an additional step. Thus, it will take two steps (amidoxime preparation, and one-pot cyclization/dehydration) to prepare substituted 1,2,4-oxadiazoles. One-pot, three-component preparation of disubstituted 1,2,4-oxadiazoles was reported recently through two-step microwave-assisted reaction of nitriles, hydroxylamine and aldehydes. ${ }^{18}$

In the present study, we report an efficient and simple synthesis of new 1,2,4-oxadiazoles (5a-i) in high yield via an one-pot reaction of nitriles $\mathbf{1}$, hydroxylamine $\mathbf{2}$, and crotonoyl chloride $\mathbf{3}$ as reactants. A more concise synthesis would be the reaction of various arylnitriles $\mathbf{1}(\mathbf{a}-\mathbf{i})$ and a hydroxylamine $\mathbf{2}$ through a solvent-free condensation to give an aryl amidoxime 4, followed by esterification in tetrahydrofuran (THF) and cyclization/dehydration in dimethyl sulphoxide (DMSO) to give 1,2,4-oxadiazole (scheme 1). In general, there is no need to remove THF after esterification and both cyclizations/dehydrations are facilitated in high temperatures by addition of DMSO, and therefore these three steps may proceed in one-pot.

\section{Experimental}

\subsection{General remarks}

${ }^{1} \mathrm{H}$ and ${ }^{13} \mathrm{C}$ NMR spectra were measured on a Bruker DRX 500 AVANCE apparatus at 500 and $125 \mathrm{MHz}$ frequencies, respectively. Infrared spectra were recorded 


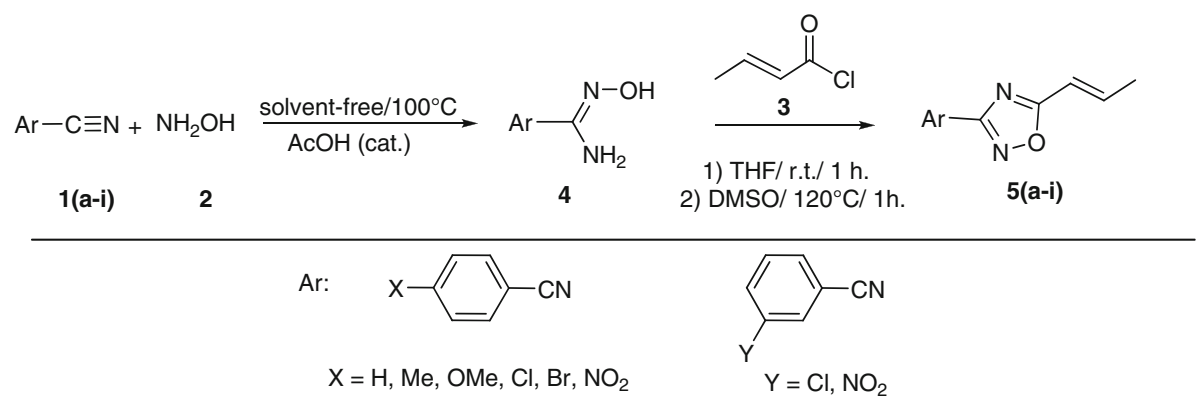

Scheme 1. One-pot synthesis of 1,2,4-oxadiazole derivatives.

in potassium bromide pellets on a FT-IR Bruker Tensor 27 over the range $400-4000 \mathrm{~cm}^{-1}$. Elemental analysis performed by a Perkin Elmer 2004 (II) CHN Analyzer. Melting points were measured with an Electrothermal Engineering LTD 9200 apparatus. Gas chromatography-mass spectrometry (GC-MS) spectra were recorded on an Agilent Technologies 6890 Network GC System and an Agilent 5973 Network Mass Selective Detector. Also, all reported yields are referred to isolated compounds.

\subsection{General procedure for the synthesis of 1,2,4-oxadiazoles}

A mixture of 4-methoxybenzonitrile $(0.23 \mathrm{~g}, 2 \mathrm{mmol})$, hydroxylamine $50 \%(0.20 \mathrm{~g}, 3 \mathrm{mmol})$ and a catalytic amount of $\mathrm{AcOH}$ (2-3 drops) was stirred at $100^{\circ} \mathrm{C}$ for $2 \mathrm{~h}$. After nearly complete conversion into an intermediate presumed to be the corresponding amidoxime, as indicated by TLC monitoring, the reaction mixture was cooled to room temperature, then crotonoyl chloride $(0.19 \mathrm{~g}, 2 \mathrm{mmol})$ was added to the cooled reaction mixture in the presence of 4-5 drops of THF and stirring continued for $1 \mathrm{~h}$ at room temperature. Next, the temperature was increased and DMSO $(1 \mathrm{~mL})$ was added to the reaction mixture, which was stirred at $120^{\circ} \mathrm{C}$ for a further $1 \mathrm{~h}$. For the $\mathbf{5 c - i}$, after cooling to room temperature, the reaction mixture stayed overnight. The obtained crystalline products washed thrice with ethanol and dried at $40-50^{\circ} \mathrm{C}$. 1,2,4-Oxadiazole derivatives were analytically pure without recrystallization. Oily products of the entries $\mathbf{5 a}$ and $\mathbf{5 b}$ were purified by column chromatography using petroleum ether-ethyl acetate (9:1).

The physical and spectral data of the products are as follows.

2.2a (E)-3-phenyl-5-(prop-1-enyl)-1,2,4-oxadiazole

(5a): Oily; $v_{\max }$ IR (KBr): 3061, 2925, 1664, 1590,
1473, $1364 \mathrm{~cm}^{-1} ;{ }^{1} \mathrm{H}$ NMR $\left(500 \mathrm{MHz}, \mathrm{CDCl}_{3}\right) \delta_{\mathrm{H}}$ : $2.06-2.08\left(\mathrm{dd}, J=6.9,1.6 \mathrm{~Hz}, 3 \mathrm{H}, \mathrm{CH}_{3}\right), 6.50$ $6.54(\mathrm{dq}, J=16.0,1.6 \mathrm{~Hz}, 1 \mathrm{H}, \mathrm{CH}), 7.16-7.24(\mathrm{dq}$, $J=15.9,6.9 \mathrm{~Hz}, 1 \mathrm{H}, \mathrm{CH}), 7.50-7.55(\mathrm{~m}, 3 \mathrm{H}, \mathrm{ArH})$, 8.12-8.14 (m, 2H, ArH); $\left.{ }^{13} \mathrm{C} \mathrm{NMR} \mathrm{(125} \mathrm{MHz,} \mathrm{CDCl}_{3}\right)$ $\delta_{\mathrm{C}}: 19.31,115.43,127.45,127.82,129.22,131.47$, 143.25, 168.89, 175.18; MS $m / z 186\left(\mathrm{M}^{+}\right), 158,144$, 133, 116, 105, 90, 77, 64, 53, 41. Anal. Calcd. for $\mathrm{C}_{11} \mathrm{H}_{10} \mathrm{~N}_{2} \mathrm{O}$; C, 70.95; H, 5.41; N, 15.0. Found: C, $70.78 ; \mathrm{H}, 5.55 ; \mathrm{N}, 14.91$.

$2.2 \mathrm{~b}$ (Z)-3-phenyl-5-(prop-1-enyl)-1,2,4-oxadiazole (5b): Oily; $v_{\max }$ IR (KBr): 3061, 2955, 1666, 1578, 1473, $1369 \mathrm{~cm}^{-1} ;{ }^{1} \mathrm{H}$ NMR $\left(500 \mathrm{MHz}, \mathrm{CDCl}_{3}\right) \delta_{\mathrm{H}}$ : $2.37-2.39$ (dd, $\left.J=6.7,1.5 \mathrm{~Hz}, 3 \mathrm{H}, \mathrm{CH}_{3}\right), 5.02-5.04$ $(\mathrm{dq}, J=11.0,1.3 \mathrm{~Hz}, 1 \mathrm{H}, \mathrm{CH}), 6.50-6.56(\mathrm{~m}, 1 \mathrm{H}$, $\mathrm{CH}), 7.52-7.57$ (m, 3H, ArH), 8.15-8.17 (dd, $J=8.0$, $2.5 \mathrm{~Hz}, 2 \mathrm{H}, \mathrm{ArH}) ;{ }^{13} \mathrm{C}$ NMR $\left(125 \mathrm{MHz}, \mathrm{CDCl}_{3}\right) \delta_{\mathrm{C}}$ : $14.35,116.02,124.55,127.68,129.25,131.55,141.25$, 169.08, 175.12; MS $m / z 186\left(\mathrm{M}^{+}\right), 158,133,118$, 105, 93, 77, 64. Anal. Calcd. for $\mathrm{C}_{11} \mathrm{H}_{10} \mathrm{~N}_{2} \mathrm{O} ; \mathrm{C}, 70.95$; H, 5.41; N, 15.04. Found: C, 70.75; H, 5.58; N, 14.96 .

\section{2c (E)-5-(prop-1-enyl)-3-p-tolyl-1,2,4-oxadiazole}

(5c): White crystals; mp $68-70^{\circ} \mathrm{C}$; $v_{\max }$ IR (KBr): $3060,2965,1660,1445,1367 \mathrm{~cm}^{-1} ;{ }^{1} \mathrm{H} \quad \mathrm{NMR}$ $\left(500 \mathrm{MHz}, \mathrm{CDCl}_{3}\right) \delta_{\mathrm{H}}: 2.06-2.08(\mathrm{dd}, J=6.9,1.7 \mathrm{~Hz}$, $\left.3 \mathrm{H}, \mathrm{CH}_{3}\right), 2.33$ (s, 3H, $\left.\mathrm{CH}_{3}\right), 6.50-6.54$ (dq, $J=17.0$, $1.7 \mathrm{~Hz}, 1 \mathrm{H}, \mathrm{CH}), 7.03-7.06(\mathrm{~m}, 1 \mathrm{H}, \mathrm{CH}), 7.25-7.27(\mathrm{~d}$, $J=8.5 \mathrm{~Hz}, 2 \mathrm{H}, \operatorname{ArH}), 8.12-8.14(\mathrm{~d}, J=8.8 \mathrm{~Hz}, 2 \mathrm{H}$, $\mathrm{ArH}) ;{ }^{13} \mathrm{C}$ NMR $\left(125 \mathrm{MHz}, \mathrm{CDCl}_{3}\right) \delta_{\mathrm{C}}: 19.31,55.85$, 114.60, 115.51, 119.99, 129.42 143.00, 162.35, 168.68, 174.94; MS $m / z 200\left(\mathrm{M}^{+}\right), 130,116,105,91,77,69$, 41. Anal. Calcd. for $\mathrm{C}_{12} \mathrm{H}_{12} \mathrm{~N}_{2} \mathrm{O} ; \mathrm{C}, 71.98 ; \mathrm{H}, 6.04 ; \mathrm{N}$, 13.99. Found: C, 71.78; H, 6.11; N, 13.91.

2.2d (E)-3-(4-methoxyphenyl)-5-(prop-1-enyl)-1,2,4oxadiazole $(5 \boldsymbol{d})$ : White crystals; $\mathrm{mp} 84-86^{\circ} \mathrm{C}$; $v_{\max }$ IR (KBr): 3032, 2929, 1664, 1611, 1584, 1543, 1442, 
$1363 \mathrm{~cm}^{-1} ;{ }^{1} \mathrm{H}$ NMR $\left(500 \mathrm{MHz}, \mathrm{CDCl}_{3}\right) \delta_{\mathrm{H}}: 2.06-2.08$ $\left(\mathrm{dd}, J=7.0,1.7 \mathrm{~Hz}, 3 \mathrm{H}, \mathrm{CH}_{3}\right), 3.90\left(\mathrm{~s}, 3 \mathrm{H}, \mathrm{CH}_{3}\right)$, $6.48-6.52(\mathrm{dq}, J=17.0,1.5 \mathrm{~Hz}, 1 \mathrm{H}, \mathrm{CH}), 7.01-$ $7.03(\mathrm{~d}, J=8.8 \mathrm{~Hz}, 2 \mathrm{H}, \mathrm{ArH}), 7.14-7.20(\mathrm{~m}, 1 \mathrm{H}$, $\mathrm{CH}), 8.05-8.07(\mathrm{~d}, J=8.8 \mathrm{~Hz}, 2 \mathrm{H}, \mathrm{ArH}) ;{ }^{13} \mathrm{C} \mathrm{NMR}$ $\left(125 \mathrm{MHz}, \mathrm{CDCl}_{3}\right) \delta_{\mathrm{C}}: 19.30,55.79,114.62,115.48$, $119.90,129.41,143.03,162.26,168.57,174.91$; MS $m / z 216\left(\mathrm{M}^{+}\right), 149,134,120,106,90,69,55,41$. Anal. Calcd. for $\mathrm{C}_{12} \mathrm{H}_{12} \mathrm{~N}_{2} \mathrm{O}_{2} ; \mathrm{C}, 66.65 ; \mathrm{H}, 5.59 ; \mathrm{N}$, 12.96. Found: C, 66.50; H, 5.75; N, 12.80.

2.2e (E)-3-(4-chlorophenyl)-5-(prop-1-enyl)-1,2,4oxadiazole (5e): White crystals; $\mathrm{mp} 72-73^{\circ} \mathrm{C} ; v_{\max }$ IR (KBr): 3057, 2921, 1657, 1583, 1468, 1408, $1358 \mathrm{~cm}^{-1} ;{ }^{1} \mathrm{H}$ NMR $\left(500 \mathrm{MHz}, \mathrm{CDCl}_{3}\right) \delta_{\mathrm{H}}: 2.07-$ 2.09 (dd, $\left.J=7.0,1.5 \mathrm{~Hz}, 3 \mathrm{H}, \mathrm{CH}_{3}\right), 6.49-6.53(\mathrm{dq}$, $J=16.0,1.6 \mathrm{~Hz}, 1 \mathrm{H}, \mathrm{CH}), 7.18-7.23(\mathrm{~m}, 1 \mathrm{H}, \mathrm{CH})$, $7.48-7.50(\mathrm{~d}, J=8.5 \mathrm{~Hz}, 2 \mathrm{H}, \operatorname{ArH}), 8.06-8.07(\mathrm{~d}$, $J=8.5 \mathrm{~Hz}, 2 \mathrm{H}, \mathrm{ArH}) ;{ }^{13} \mathrm{C} \mathrm{NMR}\left(125 \mathrm{MHz}, \mathrm{CDCl}_{3}\right)$ $\delta_{\mathrm{C}}: 19.34,115.29,125.95,129.13,129.55,137.61$, 143.59, 168.08, 175.35; MS $m / z 220\left(\mathrm{M}^{+}\right), 137,125$, 111, 102, 90, 75, 63, 50. Anal. Calcd. for $\mathrm{C}_{11} \mathrm{H}_{9} \mathrm{ClN}_{2} \mathrm{O}$; C, 59.88; H, 4.11; N, 12.70. Found: C, 59.80; H, 4.32; N, 12.64 .

$2.2 \mathrm{f}$ (E)-3-(3-chlorophenyl)-5-(prop-1-enyl)-1,2,4oxadiazole (5f): White crystals; mp $69-70^{\circ} \mathrm{C}$; $v_{\max }$ IR (KBr): 3046, 2940, 1651, 1586, 1537, 1448, 1400, $1379 \mathrm{~cm}^{-1} ;{ }^{1} \mathrm{H}$ NMR $\left(500 \mathrm{MHz}, \mathrm{CDCl}_{3}\right) \delta_{\mathrm{H}}: 2.05-$ $2.07\left(\mathrm{dd}, J=7.1,1.5 \mathrm{~Hz}, 3 \mathrm{H}, \mathrm{CH}_{3}\right), 6.46-6.50(\mathrm{dq}$, $J=15.9,1.6 \mathrm{~Hz}, 1 \mathrm{H}, \mathrm{CH}), 7.10-7.13(\mathrm{~m}, 1 \mathrm{H}, \mathrm{CH})$, 7.44-7.47 (m, 2H, ArH), 8.00 (s, 1H, ArH), 8.15$8.17(\mathrm{~d}, J=8.0 \mathrm{~Hz}, 1 \mathrm{H}, \mathrm{ArH}) ;{ }^{13} \mathrm{C}$ NMR $(125 \mathrm{MHz}$, $\left.\mathrm{CDCl}_{3}\right) \delta_{\mathrm{C}}: 19.35,115.33,125.07,125.91,129.32$, 129.86, 130.55, 137.62, 142.60, 168.11, 175.38; MS $m / z 220\left(\mathbf{M}^{+}\right), 137,125,111,103,90,76,61$. Anal. Calcd. for $\mathrm{C}_{11} \mathrm{H}_{9} \mathrm{ClN}_{2} \mathrm{O} ; \mathrm{C}, 59.88 ; \mathrm{H}, 4.11 ; \mathrm{N}, 12.70$. Found: C, 59.94; H, 4.28; N, 12.58 .

2.2g (E)-3-(4-nitrophenyl)-5-(prop-1-enyl)-1,2,4oxadiazole $(\mathbf{5 g})$ : White crystals; $\mathrm{mp} 69-70^{\circ} \mathrm{C} ; v_{\max }$ IR (KBr) 3046, 2925, 1653, 1604, 1536, 1467, 1408, $1347 \mathrm{~cm}^{-1}$; ${ }^{1} \mathrm{H}$ NMR $\left(500 \mathrm{MHz}, \mathrm{CDCl}_{3}\right) \delta_{\mathrm{H}}: 2.10$ $2.12\left(\mathrm{dd}, J=7.1,1.5 \mathrm{~Hz}, 3 \mathrm{H}, \mathrm{CH}_{3}\right), 6.53-6.56(\mathrm{dq}$, $J=15.6,1.6 \mathrm{~Hz}, 1 \mathrm{H}, \mathrm{CH}), 7.24-7.29(\mathrm{~m}, 1 \mathrm{H}, \mathrm{CH})$, $8.32-8.34(\mathrm{~d}, J=8.0 \mathrm{~Hz}, 2 \mathrm{H}, \operatorname{ArH}), 8.38-8.40(\mathrm{~d}$, $J=8.0 \mathrm{~Hz}, 2 \mathrm{H}, \mathrm{ArH}) ;{ }^{13} \mathrm{C} \mathrm{NMR}\left(125 \mathrm{MHz}, \mathrm{CDCl}_{3}\right)$ $\delta_{\mathrm{C}}: 19.32,115.35,125.0,125.95,129.24,129.59$, 137.68, 143.64, 168.18, 175.38; MS $m / z 231\left(\mathrm{M}^{+}\right)$, 201, 185, 164, 134, 106, 88, 68, 54, 41. Anal. Calcd. for $\mathrm{C}_{11} \mathrm{H}_{9} \mathrm{~N}_{3} \mathrm{O}_{3} ; \mathrm{C}, 57.14 ; \mathrm{H}, 3.92 ; \mathrm{N}, 18.17$. Found: C, $57.10 ; \mathrm{H}, 4.01 ; \mathrm{N}, 18.21$. 2.2h (E)-3-(3-nitrophenyl)-5-(prop-1-enyl)-1,2,4oxadiazole $(\mathbf{5} \boldsymbol{h})$ : White crystals; $\mathrm{mp} 73-76^{\circ} \mathrm{C} ; v_{\max }$ IR (KBr): 3045, 2920, 1659, 1600, 1535, 1463, 1408, $1337 \mathrm{~cm}^{-1} ;{ }^{1} \mathrm{H}$ NMR $\left(500 \mathrm{MHz}, \mathrm{CDCl}_{3}\right) \delta_{\mathrm{H}}: 2.05-$ $2.07\left(\mathrm{dd}, J=6.8,1.7 \mathrm{~Hz}, 3 \mathrm{H}, \mathrm{CH}_{3}\right), 6.54-6.57(\mathrm{dq}$, $J=16.0,1.7 \mathrm{~Hz}, 1 \mathrm{H}, \mathrm{CH}), 7.24-7.29(\mathrm{~m}, 1 \mathrm{H}, \mathrm{CH})$, $7.72-7.74(\mathrm{t}, J=8.5 \mathrm{~Hz}, 1 \mathrm{H}, \operatorname{ArH}), 8.23-8.25(\mathrm{~d}$, $J=8.0 \mathrm{~Hz}, 1 \mathrm{H}, \mathrm{ArH}), 8.58-8.61(\mathrm{~m}, 2 \mathrm{H}, \mathrm{ArH}) ;{ }^{13} \mathrm{C}$ NMR $\left(125 \mathrm{MHz}, \mathrm{CDCl}_{3}\right) \delta_{\mathrm{C}}: 19.20,115.22,125.13$, $125.98,129.29,129.80,130.55,137.64,142.66$, 168.10, 175.35; MS $m / z 231\left(\mathbf{M}^{+}\right), 201,185,164$, 134, 106, 89, 68, 53, 41. Anal. Calcd. for $\mathrm{C}_{11} \mathrm{H}_{9} \mathrm{~N}_{3} \mathrm{O}_{3}$; C, 57.14; H, 3.92; N, 18.17. Found: C, 57.09; H, 3.98; N, 18.29.

$2.2 \mathrm{i}$ (E)-3-(4-bromophenyl)-5-(prop-1-enyl)-1,2,4oxadiazole (5i): White crystals; mp $92-94^{\circ} \mathrm{C}$; $v_{\max } \mathrm{IR}$ (KBr) 3056, 2908, 1657, 1598, 1537, 1401, $1355 \mathrm{~cm}^{-1}$; ${ }^{1} \mathrm{H}$ NMR $\left(500 \mathrm{MHz}, \mathrm{CDCl}_{3}\right) \quad \delta_{\mathrm{H}}: 2.07-2.09$ (dd, $\left.J=7.0,1.8 \mathrm{~Hz}, 3 \mathrm{H}, \mathrm{CH}_{3}\right), 6.49-6.53(\mathrm{dq}, J=15.9$, $1.8 \mathrm{~Hz}, 1 \mathrm{H}, \mathrm{CH}), 7.16-7.24(\mathrm{~m}, 1 \mathrm{H}, \mathrm{CH}), 7.64-7.66$ $(\mathrm{d}, J=8.6 \mathrm{~Hz}, 2 \mathrm{H}, \mathrm{ArH}), 7.98-8.00(\mathrm{~d}, J=8.5 \mathrm{~Hz}$, $2 \mathrm{H}, \mathrm{ArH}) ;{ }^{13} \mathrm{C}$ NMR $\left(125 \mathrm{MHz}, \mathrm{CDCl}_{3}\right) \delta_{\mathrm{C}}: 19.35$, $115.27,126.03,126.40,129.33,132.51,143.62$, 168.17, 175.37; MS $m / z 264\left(\mathrm{M}^{+}\right), 197,181,155$, 132, 117, 90, 69, 54, 39. Anal. Calcd. for $\mathrm{C}_{11} \mathrm{H}_{9} \mathrm{BrN}_{2} \mathrm{O}$; C, 49.84; H, 3.42; N, 10.57. Found: C, 49.65; H, 3.70; N, 10.45 .

\section{Results and discussion}

As a part of our continuing efforts to develop efficient methods for the preparation of widely used organic compounds from readily available building blocks, ${ }^{19}$ this study deals with the introduction of a new and very simple method for the synthesis of 3-aryl-5-(prop-1-enyl)-1,2,4-oxadiazoles. For this reason, a mixture of the arylnitriles $\mathbf{1}$ and hydroxylamine 2 was converted in situ into amidoximes 4 . Next, the intermediate amidoxime compounds (4) were converted into corresponding 3-aryl-5-(prop-1-enyl)-1,2,4oxadiazoles with crotonoyl chloride $(3)$ in the presence of THF at room temperature followed by the addition of higher boiling point solvent (DMSO) and stirring for $1 \mathrm{~h}$ at $120^{\circ} \mathrm{C}$. The synthetic procedure is outlined in scheme 1 and as shown in table 1, isolated yields of the prepared compounds were in the range of $60-75 \%$.

To establish the generality of the method, a variety of available substrates were employed (table 1). The structure of these synthesized compounds was confirmed by IR and ${ }^{1} \mathrm{H}$, and ${ }^{13} \mathrm{C}$ NMR spectroscopy as well as MS 
Table 1. Synthesis 1,2,4-oxadiazole derivatives 5a-i.

5a

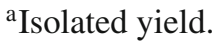

and elemental analyses. For instance, in the IR spectrum of 5a, the characteristic bands of amidoxime primary amine (3455 and $3360 \mathrm{~cm}^{-1}$ ) and ester groups of a crotonoyl chloride $\left(1720 \mathrm{~cm}^{-1}\right)$ in the reactant were completely disappeared. In the ${ }^{1} \mathrm{H}$ NMR spectrum, resonance signals at downfield regions $8.12-8.14 \mathrm{ppm}$ are ascribed to the two ortho-proton of aromatic ring and two doublet of quarted around 6.50-6.54 and 7.16-7.24 with the same vicinal coupling constant around $1.6 \mathrm{~Hz}$ are ascribed to the allylic protons. Also, the area of integration for the protons is in accordance with the assignment. ${ }^{13} \mathrm{C}$ NMR spectrum of $\mathbf{5 a}$ reveals that two carbons of the hetrocycle ring resonate in the downfield at 168.89 and $175.18 \mathrm{ppm}$. The chemical shift in the upfield region (19.31 ppm) is ascribed to the resonance of aliphatic methyl group. In addition to IR and NMR spectra, the elemental analysis and mass spectra results of 5a also generally agreed with the proposed structures.
The most probable mechanism for this reaction is illustrated in scheme 2 .<smiles>C/C=C(/C(=O)Cl)C(C)C</smiles><smiles>C/C=C/C(=O)O/N=C(/N)Br</smiles>

4
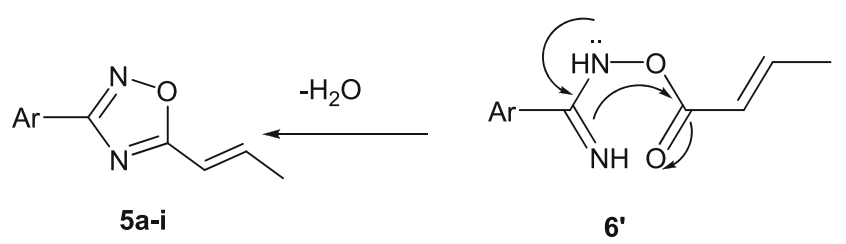

Scheme 2. Plausible mechanism for the formation of $\mathbf{5 a}-\mathbf{i}$. 


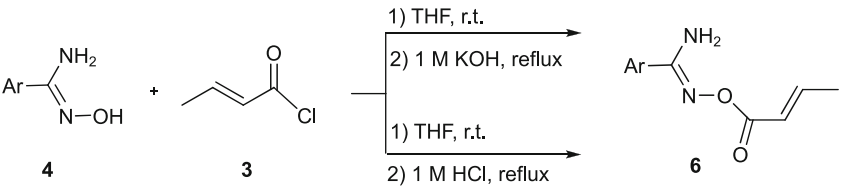

Scheme 3. Reaction between amidoximes and crotonoyl chloride in different conditions.

Initially in the presence of THF, estrification reaction occurred between amidoxime and crotonoyl chloride. Owing to better nucleophilicity of the oxygen atom compared to amidic nitrogen atom, ${ }^{20}$ oxygen atom attacks the crotonoyl chloride carbonyl group. Then, DMSO was added and this intermediate is cyclized to the 3-aryl-5-(prop-1-enyl)-1,2,4-oxadiazoles derivatives $(\mathbf{5 a}-\mathbf{i})$ after stirring for $1 \mathrm{~h}$ at $120^{\circ} \mathrm{C}$. A variety of different conditions to obtain cyclic products were examined, including basic and acidic conditions (scheme 3). However, both conditions resulted in the corresponding $\mathrm{O}$-acylamidoxime $\mathbf{6}$ as a major product.

When benzonitrile was used as a reactant, the products were a mixture of compounds $\mathbf{5 a}$ and $\mathbf{5 b}$ with yields of $75 \%$ and $10 \%$, respectively (table 1). The GCMS analysis revealed the same pattern for both compounds and analysis of ${ }^{1} \mathrm{H}$ NMR spectroscopy indicated that there is a mixture of cis and trans isomers. The isomers were separated by column chromatographic techniques, and the differences in the magnitude of the vicinal coupling constant $\left({ }^{3} J_{\mathrm{HH}}\right)$ of the double bond hydrogens in the ${ }^{1} \mathrm{H}$ NMR spectra was used to evaluate structural identification. Since the vicinal coupling constants are larger for trans isomers than for cis isomers, ${ }^{21}$ the $16 \mathrm{~Hz}$ coupling constant value measured for major isomer, was attributed to the trans isomer.

\section{Conclusion}

In summary, we have introduced a simple and one-pot procedure for the synthesis of 1,2,4-oxadiazoles without using any dehydrating agent or support. Reaction occurred in a short time without any work-up process and this method was applicable for arylnitriles substituted with both electron donor or acceptor groups, demonstrating proof-of-concept for the rapid synthesis of focused libraries of small molecule heterocycles based on this scaffold.

\section{References}

1. Ricardo A W and Neves F A 2006 Molecules 11318

2. Hemming K 2001 J. Chem. Res. 216209

3. Farooqui M, Bora R and Patil C R 2009 Eur. J. Med. Chem. 44794

4. Watjen F, Baker R, Engelstoff M, Herbert R, MacLeod A, Knight A, Merchant K, Moseley J, Saunders J and Swain C J 1989 J. Med. Chem. 322282

5. Ankersen M, Peschke B, Hansen B S and Hansen T K 1997 Bioorg. Med. Chem. Lett. 71293

6. Bethge K, Pertz H H and Rehse K 2005 Arch. Pharm. 33878

7. Ganesh R, Jadhav M U, Shaikh R P, Kale A R and Ghawalkar C H 2009 J. Heterocycl. Chem. 46 980

8. Adib M, Mahdavi M, Mahmoodi N, Pirelahi $\mathrm{H}$ and Bijanzadeh H R 2006 Synlett 111765

9. Van Wagenen B C, Stormann T M, Moe S T, Sheehan S M, McLeod D A, Smith D L, Isaac M G and Slassi A 2001 Appl. P. I. WO 2002068417, NPS Pharmaceuticals, Inc

10. Augustine J K, Akabote V, Hegde S G and Alagarsamy P 2009 J. Org. Chem. 745640

11. Chao Quan C and Kurth M 2004 J. Org. Chem. 691470

12. de Freitas J J R, de Freitas J C R, Ladjane L P, da Silva P, de Freitas Filho J R, Kimura G Y V, Rajendra M and Srivastava R M 2007 Tetrahedron Lett. 48 6195

13. Katritzky A R, Shestopalov A A, Suzuki K, Katritzky A R, Shestopalov A A A and Suzuki K 2005 Arkivok 736

14. Kaboudin B and Saadati F 2005 J. Heterocycl. Chem. 42699

15. Kaboudin B and Saadati F 2007 Tetrahedron Lett. 48 2829

16. Rostamizadeh S, Ghaieni H R, Aryan R and Amani A M 2010 Tetrahedron 66494

17. Du W, Hagmann W K and Hale J J 2006 Tetrahedron Lett. 474271

18. Adib M, Haghighat Jahromi A, Tavoosi N, Mahdavi M and Bijanzadeh H R 2006 Tetrahedron Lett. 47 2965

19. (a) Heravi M M, Sadjadi S, Mokhtari Haj N, Oskooie H A, Hekmat Shoar R and Bamoharram F F 2009 Tetrahedron Lett. 50 943; (b) Heravi M M, Bakhtiari K, Zadsirjan V, Bamoharram F F and Heravi O M 2007 Bioorg. Med. Chem. Lett. 174262

20. Srivastava R M, Morais L P F, Melo Souto S C, Carpenter G B and Carvalho L T 2006 Tetrahedron Lett. 473173

21. Williams D H and Leming I F 1989 Spectroscopic methods in organic chemistry, 4th ed. (revised), (Berkshire, UK: McGraw-Hill Book Company) Limited, Table 3-27 